\title{
EL DESENGAÑo DEL NATURALISMO: ANÁLISIS DE LA EVOLUCIÓN DE ALGUNOS NOVELISTAS ESPAÑOLES DEL SIGLO XIX *
}

\author{
ÓSCAR BARRERo PÉREZ \\ Universidad Autónoma de Madrid
}

I

Zola había sido objeto de controversia desde sus primeros pasos naturalistas, pero, a raíz de la publicación de La tierra (1887), las censuras a sus excesos se habían intensificado. En ese año, un grupo de jóvenes escritores (aquellos en los que se supone que la semilla naturalista debiera haber fructificado) pasaría a la Historia como firmante del llamado Manifiesto de los Cinco, duramente crítico con el giro dado por Zola a su literatura. La unidad de aquel naturalista grupo de Médan que en 1880 había publicado un libro colectivo de relatos (Soirées de Médan) comenzaba a resquebrajarse: la ruptura era ya evidente cuando, en 1891, Joris-Karl Huysmans, uno de los integrantes de la agrupación (los otros eran Maupassant, Paul Alexis, Léon Hennique y Henry Céard), publicó Allá lejos, novela que abría el camino al naturalismo espiritual, que ya por entonces en Francia recibía ese nombre. La citada obra se iniciaba precisamente con una discusión sobre el naturalismo, a partir de la cual el protagonista, Durtal, reflexionaba en estos términos:

Sería necesario seguir la ancha vía abierta tan profundamente por Zola; pero también se necesitaría trazar en el aire un camino paralelo, otra ruta, uniendo las dos, creando, finalmente, un naturalismo espiritualista. ¡Eso sí que sería lo hermoso, lo completo, lo fuerte! '.

El explícito respeto a la labor precursora de Zola es aquí tan evidente como la cercanía del autor a una nueva narrativa, la espiritualista, que

* Este trabajo completa otro mío anterior, publicado en Anuario de Estudios Filológicos, XXII (1999), con el título «Revisión crítica del naturalismo. Actualización de un debate histórico» (pp. 55-71). A él remito para más precisiones y una ampliación bibliográfica.

1 Cito por la traducción de Germán Gómez de la Mata (Barcelona, Bruguera, 1986, p. 15).

Rlit, LXIV, 127 (2002), 63-92 
Huysmans, desdoblado en su criatura literaria, personificaba en la figura de Dostoyevski, mencionado en ese primer capítulo como escritor próximo al ideal por el que en esos años comenzaba a decantarse la literatura española.

Ese mismo año 1891 registra la aparición, en Echo de Paris (3 de marzo al 5 de julio), de una encuesta que confirmaba el declive del naturalismo, punto en el que todos los interrogados parecían estar de acuerdo. Pardo Bazán, siempre atenta a la novedad procedente de Francia, decretaría ante sus lectores españoles ese mismo ocaso de que ya se hablaba al otro lado de la frontera.

¿De qué forma los escritores españoles más importantes asumieron la llegada de los nuevos tiempos, aquellos que recomendaban la sustitución de nombres positivistas como los de Taine o Darwin por otros más próximos al irracionalismo filosófico: Schopenhauer, Nietzsche?

La evolución de Galdós ha sido objeto de estudios abundantes, que han aclarado los pasos de un proceso de indagación permanente en la interioridad del hombre. No estaría de más, dicho sea de paso, recordar estas palabras suyas citadas por Luis López Jiménez en su trabajo sobre Lo prohibido: "Aun admirando a Zola y haciéndome sentir y pensar mucho sus novelas, no se me ocurrió nunca hacerlas a su manera» ${ }^{2}$. La búsqueda de lo interior terminó siendo el punto de mira de Galdós, como lo fue el de Clarín en sus cuentos y en Su único hijo. Pardo Bazán alimentaba el fuego de la polémica con sus artículos y su actitud combativa (es decir: con su discurso), pero era Galdós quien trasplantaba a la práctica de la novela la postura teórica de renovación: él había dado paso al realismo y él había escrito la primera novela que entonces se consideró naturalista. Sería también él quien avanzara el espiritualismo en Fortunata y Jacinta (1886-87), Miau (1888), La incógnita (1889) y Realidad (1890), en unos años en que Pardo Bazán aún creía en las posibilidades de un naturalismo atenuado, el de Los pazos de Ulloa (1886) y La madre naturaleza (1887).

\section{II}

El de Pardo Bazán es un caso distinto del de Galdós, porque a ella no la mueve un impulso de insatisfacción permanente, sino el anhelo de una estabilidad que no consiguió alcanzar hasta bien entrado el siglo $\mathrm{XX}^{3}$. Sus

\footnotetext{
2 "Lo prohibido», de B. Pérez Galdós: naturalismo y Regencia, Madrid, Ayuntamiento-Instituto de Estudios Madrileños, 1995, p. 8.

${ }^{3}$ Discrepo de Mary Lee BRETZ cuando atribuye a la escritora gallega el papel de pivote ideológico/sexual en el debate acerca del naturalismo, hasta el punto de articular sobre ella (y, de manera más tangencial, sobre otros aspectos todavía menos relevantes: el cantonalismo, por ejemplo) la práctica totalidad de su libro. Considera que la apari-
} 
primeros pasos narrativos revelan una aproximación técnica al naturalismo y anuncian con claridad la tensión que solo al final de su carrera, olvidadas ya las veleidades naturalistas, acertó a superar ${ }^{4}$. El conflicto central de Un viaje de novios (1881) es religioso: Lucía sufre por el satanismo del descreído Artegui, y el rechazo último que este ha de sufrir se basa únicamente en motivos de fe. El tantas veces citado prólogo de la novela no es en realidad, dígase lo que se haya dicho, una defensa del naturalismo, sino, en el fondo, una crítica de lo más sustancial de él, una sucesión de objeciones que culminan en una pregunta implícita: ¿para qué necesitamos ese naturalismo extranjero, si tenemos el realismo, tan tradicional y, sobre todo, tan nuestro? Un dato anecdótico, pero no por ello menos revelador: Pardo Bazán se muestra contraria al viaje de novios porque es «costumbre extranjera».

El paso tradicionalmente considerado como decisivo en el proceso de aproximación de Pardo Bazán al naturalismo es la publicación (1883) de

ción de Pardo Bazán en el paisaje de que hablamos «changes the nature of the debate» (Voices, Silences and Echoes. A Theory of the Essay and the Critical Reception of Naturalism in Spain, Londres, Tamesis, 1992, p. 128). "Traditionalist hysteria that women's emancipation will lead to sexual liberation and free love is echoed in liberal writings and writers of all ideological persuasions work to silence, refute, dilute, or reappropriate Pardo Bazán's word» (ibíd.). La idea, recurrente en la obra, se inserta en el corpus ideológico ginocrítico, pero padece del mismo defecto achacable a toda la teoría literaria edificada por el feminismo: la reducción de un espacio complejo en el que tienen cabida lo humano, lo estético, lo espiritual y lo ideológico a un terreno contemplado con visión muy limitada: un solo arbol impide no ya la contemplación del bosque, sino la de los demás árboles aisladamente considerados. La colocación en la misma nota del comentario de Bretz y de este otro de José Luis VÁZQUEZ DODERo no tiene más objeto que el de constatar que para la crítica también pasa el tiempo. Vázquez Dodero parte de frases de Menéndez Pelayo y Valera para sugerir que Pardo Bazán vira hacia el naturalismo por «una característica típica de la psicología de la mujer: la de prestarse dócilmente a recibir la influencia ajena» («El naturalismo y la Pardo Bazán», Nuestro Tiempo, n. ${ }^{\circ}$ 39-40 (sept.-oct. 1957), pp. 238-39).

${ }^{4}$ Lo ha resumido Francisca GONZÁLEZ ARIAS: «Fue en la novela rusa donde doña Emilia descubrió principios e ideas mucho más gratos a su temperamento que los del Naturalismo. Las corrientes místicas, los principios estéticos y el sentido social concordaban mucho más con su visión de la vida y sus ideales artísticos. La literatura rusa le ayudó a la Condesa a hallar su verdadera voz, a definirse como novelista y a concretar cuál era la fórmula que más convenía a su personalidad artística» [«La condesa, la revolución y la novela en Rusia», Bulletin Hispanique, 96 (en.-jun. 1994), p. 185]. Pero sus ideas sobre la narrativa rusa distaban mucho de ser originales: «Aunque es cierto que dice en su libro que se valió del Roman russe de Vogüé, esta concesión no basta. Cuando leemos, por ejemplo, lo que ella escribe de Gogol, nos maravillamos de su gusto crítico y de su perspicacia. Pero si entonces abrimos las páginas de Vogüé, vemos ante nuestros ojos, casi palabra por palabra, idénticas ideas. Es simplemente un plagio, y no muy bien disfrazado. Presenta ideas como si fuesen suyas, y las ha sacado del texto de otro autor» [Robert E. OSBORNE, «Emilia Pardo Bazán y la novela rusa», Revista Hispánica Moderna, 20 (oct. 1954), p. 276]. 
La Tribuna. Interpretaciones como la de Nelly Clemessy ${ }^{5}$ me eximen de extenderme en consideraciones que coincidirían, básicamente, con las suyas. Realzaré únicamente la insistencia en lo nacionalista: España no es, piensa Pardo, como Francia. Afortunadamente, acota. Pero ella misma reconoce que las miserias de las novelas de Zola están descritas con «terrible verdad». Y esa terrible verdad de que ella habla en el prólogo de $L a$ Tribuna asoma en las páginas de esta, aunque la perspectiva sea más humanista que social. La rebeldía de las cigarreras se queda en aparato verbal y el testimonio aparece cubierto con el pudoroso velo del cristianismo. Pero ¿es consciente Pardo Bazán de que, pese a sus esfuerzos por no llegar al punto al que accede el Zola más severo, la terrible verdad está ahí, y a punto de provocar convulsiones graves?

A Los pazos de Ulloa y La madre naturaleza dedicó Mariano Baquero Goyanes unas lúcidas páginas que demostraban los débitos de la autora con la literatura, débitos que poco tenían que ver con la observación naturalista $^{6}$. Interesan ahora dos conclusiones. Una: la culpabilidad de lo sucedido no es del medio, de la madre naturaleza, sino de la ignorancia de las personas, que no se han preocupado de proporcionar a los jóvenes un dato sabido por todos. Dos: la ferviente católica que es Pardo Bazán únicamente encuentra una solución, el convento, para el problema; solución todo lo tópica que se quiera, pero coherente con su forma de pensar.

Ya entonces (1887), la escritora se incluía entre los «espiritualistas», como reconocía en el capítulo II de La Revolución y la novela en Rusia, libro originado por sus conferencias en el Ateneo madrileño ${ }^{7}$. Otro paso de interés es el dado en Insolación, que, por su fecha (1889) y por su desenlace (la autora deja en absoluta libertad a personajes y lector), me

${ }^{5}$ «De La cuestión palpitante a La Tribuna: teoría y praxis de la novela en Emilia Pardo Bazán», en Iván LISSORGUES (ed.), Realismo y naturalismo en España en la segunda mitad del siglo XIX (Barcelona, Anthropos, 1988), pp. 485-96.

${ }^{6}$ La novela naturalista española: Emilia Pardo Bazán, Murcia, Universidad, ${ }^{2} 1986$. De otra forma lo ha expresado M. L. BRETZ: «Más que una confirmación del determinismo ambiental, expresado por varios de los personajes, la obra demuestra la primacía de ciertas actitudes culturales y sociales que operan lo mismo en los personajes rurales que en los educados en la ciudad» [«Naturalismo y feminismo en Emilia Pardo Bazán», Papeles de Son Armadans, n. 261 (dic. 1977), p. 200].

7 P. 115 de la edición de 1961 (Madrid, Publicaciones Españolas). Por cierto que en el mismo libro podía leerse lo siguiente: «He distinguido siempre en Zola entre el pensador y el artista. Este último es admirable, y no creo que tenga nada que envidiar a Tolstoy, ni en las condiciones de poeta épico, ni en las de pintor descriptivo. Mas al lado del artista excepcional hay un filósofo... - - debo llamarle así? - de la más ínfima y burda especie, que ha influido de modo funesto en la dirección del naturalismo francés, reduciendo el horizonte de la novela» (p. 275). Con estas palabras, Pardo Bazán se adelanta un siglo a la reciente distinción entre discurso y práctica en Zola. 
parece tan alejada ya del naturalismo programático como próxima a la novela psicológica a punto de advenir ${ }^{8}$.

Una cristiana. La prueba (1890) es el testimonio de la profunda vacilación que aqueja a Pardo Bazán. La autora no renuncia a la técnica naturalista: herencia, raza y «verídicos apuntes» hallan acomodo en el texto, pero este mantiene su asidero nacionalista, porque la mujer nueva que encarna una inglesa termina derrotada nada menos que por «el tipo de nuestra mujer ignorante y cerril» (cap. 17). En la novela no sale bien parado el espíritu experimentalista: «el arte debe ser una selección», se lee en el capítulo final. Mientras que el botánico está obligado a estudiar incluso las hierbas ponzoñosas, el artista solo debe interesarse por las más hermosas flores. Es, bien se ve, una modificación más que sustancial de la perspectiva. Y el desenlace lo refuerza: el descreído Salustio se siente «cristiano» ante los buenos sentimientos que su tío muestra en el momento de la muerte. El mundo de Pardo Bazán parece ir cerrándose en torno a los límites de la subjetividad. Pronto lo veremos enclaustrarse entre las paredes del suntuoso adorno modernista.

Un detalle más que significativo es el cambio radical que experimenta la figura del personaje del médico entre su primera aparición, en Un viaje de novios, y la que se registra en La piedra angular, novela publicada en 1891, precisamente el año en que Pardo Bazán da por cerrada la aventura histórica del naturalismo. Pues bien: si el médico de diez años antes era materialista, este de ahora concede una importancia trascendental «a los fenómenos de conciencia y a las misteriosas actividades psicofísicas», porque «formamos una totalidad, un conjunto armónico, y apenas hay males del cuerpo o del espíritu aisladamente» (cap. 1). Estas son (y lo reconoce, con las mismas palabras, la autora) las «cuestiones palpitantes» del momento. Pero son cuestiones palpitantes que le vienen sugeridas por la inquietud psicológica y no, desde luego, por Zola. Al margen de esto, La piedra angular se inscribe en el proceso de confusión literaria que acom-

\footnotetext{
${ }^{8}$ En 1971 no estaba claro el carácter naturalista de Insolación. Lo defendía Matías MONTES HUIDOBRo en su libro XIX: superficie y fondo del estilo (Valencia, Universidad de Carolina del Norte-Estudios de Hispanófila, 1971; p. 70: «La novela pertenece a la esfera de dicho determinismo naturalista»). Lo cuestionaba, en ese mismo año, Cyrus C. DECOSTER: «I question classifying Insolación as a Naturalistic novel. Absent are most of the characteristics usually associated with the movement» [«Pardo Bazán's Insolación: A Naturalistic Novel?», Romance Notes, 13 (oct. 1971), p. 90]. Ermitas PENAS, en la línea interpretativa más actual, corrobora: «Varios de los presupuestos fundamentales del roman experimental son negados. Afectan a aspectos tanto estructurales como interpretativos y estilísticos: la modalización no obedece a la impasibilidad, el tiempo de la historia es reducido, la teoría del determinismo del medio es vapuleada, lo psicológico adquiere una dimensión considerable, el sentido del humor es patente...» ["Insolación de Emilia Pardo Bazán y la crisis del naturalismo», Letras Peninsulares, 6/2-6/3 (1993-94), p. 339].
} 
paña el devenir de la última Pardo Bazán. El objetivo de la obra, si es que existe, no aparece claro, posiblemente porque tampoco la autora lo vio con nitidez ${ }^{9}$.

Pardo Bazán, en la década final del siglo XIX, sigue tanteando, pero muy imprecisamente, el camino por recorrer tras el abandono del naturalismo. En 1893 escribe, comentando El doctor Pascal, de Zola, que si «algo demuestra la última novela de Zola es que la ciencia a fines del XIX ha dado en quiebra estrepitosamente» ${ }^{10}$. Los dos últimos ciclos narrativos del escritor francés, Tres ciudades (1894-99) y Los cuatro evangelios (18991902), le merecen rechazo o, en el mejor de los casos, un silencio no precisamente aprobatorio, como recuerda David Baguley:

Sur Les Trois Villes [...] elle n'a fait que garder, paraît-il, un silence presque total, sans doute désapprobateur, étant donné les thèmes idéologiques de la nouvelle série: la recheŕche d'une religion nouvelle, la condamnation du catholicisme, le culte du progrès scientifique ${ }^{11}$.

En 1898 vuelve los ojos al romanticismo de su primera novela, Pascual López, para escribir El saludo de las brujas, donde ninguno de los ingredientes del prerrealismo falta. El texto es poco interesante, pero las preguntas que obliga a formularse no carecen de atractivo ${ }^{12}$. ¿Es realmente

${ }^{9}$ Quizá derive de ahí la confusión de lectores y críticos. ¿Naturalismo, antinaturalismo? Es posible que la lectura más actual sea la segunda, pero todavía hoy se defiende la primera, como hace Benito VARELA JÁCOME cuando afirma que con La piedra angular «el empleo de procedimientos naturalistas por Pardo Bazán se intensifica» $[\ll E l$ experimento narrativo de La piedra angular: naturalismo y doctrinas criminalistas», en José Manuel GonZÁlez HerRÁn (ed.), Estudios sobre Emilia Pardo Bazán. In memoriam Maurice Hemingway, Santiago de Compostela, Universidad-Consorcio, 1997, p. 354]. Quizá no sea tan anecdótico el hecho de que, como recuerda Mercedes ETREROS, La piedra angular es la única de las novelas de Pardo Bazán publicadas entre 1890 y 1896 que no está escrita en primera persona [«Influjo de la narrativa rusa en doña Emilia Pardo Bazán. El ejemplo de La piedra angular», Anales de Literatura Española, n. ${ }^{\circ} 9$ (1993), p. 36]. Para J. M. GonZÁLEZ HERRÁN, es difícil esbozar el perfil ideológico de Pardo en este momento, «habida cuenta de lo borroso e impreciso de la evolución de su pensamiento» [«Emilia Pardo Bazán ante el 98 (1896-1903)», en Leonardo ROMERO TOBAR (ed.), El camino hacia el 98 (los escritores de la Restauración y la crisis del fin de siglo) (Madrid, Visor-Fundación Duques de Soria, 1998), p. 142].

10 En Nuevo Teatro Crítico, cit. por Marisa SOTELO VÁZQUEZ [«La recepción crítica de Le Docteur Pascal (1893), de É. Zola, en España», en Simone SAILlARD y Adolfo SOTElo VÁzQueZ (eds.), Zola y España. Actas del Coloquio Internacional (Barcelona, Universidad, 1997), p. 134].

11 «Emilia Pardo Bazán et le troisième Zola», en S. SAILlard y A. SOTElo VÁzQuEZ (eds.), Zola y España (cit.), p. 150.

12 Coincido con N. ClEMESSY, para quien esta «ficción modernista», como ella la llama, es de un «romanticismo asaz descabellado» [«Selva, de Emilia Pardo Bazán. Una tentativa frustrada de novela policíaca», en J. M. GonZÁlEZ HERRÁN (ed.), Estudios sobre Emilia Pardo Bazán (cit.), p. 91]. 
un paso atrás, un retorno a los orígenes de quien ha sufrido el desengaño inducido por un naturalismo válido en un cierto momento, pero superado ya en los estertores del siglo? ¿O es un paso adelante hacia el subjetivismo absoluto? Cualquiera que sea la respuesta, el concepto de hipotexto romántico pudiera tener algo que decir: punto inicial del proceso (romanticismo) y punto final (subjetivismo decadentista o espiritualista) conectan, asfixiando el realismo y el naturalismo ${ }^{13}$. En un antiguo, pero penetrante artículo, John W. Kronik había analizado esta misma cuestión del residuo romántico en La literatura francesa moderna:

The link she established between the two periods in question by no means resulted from a moment of critical aberration on her part. Not only did she show acute observation in certain matters of detail, but she was in consonance with critics of our own day who, delving more deeply into the problem, have tended to view the entire nineteenth and twentieth centuries as a cultural development of romanticism and romanticism itself as a dynamic force that has not get been supereded ${ }^{14}$.

No escasean los testimonios de la propia Pardo que nos muestran a una escritora renuente a olvidar no ya los orígenes románticos, sino la misma esencia de lo romántico. En dos artículos distintos lo recuerda M. Sotelo Vázquez. En uno cita La literatura francesa moderna: «Acaso el sentir romántico sea eterno, aunque se transforma su expresión literaria» ${ }^{15}$. En otro, el prólogo de El Cisne de Vilamorta:

\footnotetext{
No hay estado del alma que no se produzca en el hombre, no hay carácter verdaderamente humano que no se encuentre queriéndolo buscar; y en nuestras pensadoras y concentradas razas del Noroeste el espíritu romántico alienta más de lo que parece a primera vista ${ }^{16}$.
}

La esquizofrenia ideológica y sentimental de Pardo la lleva a mantener una ambigua relación con ese romanticismo que considera superado por el paso del tiempo, pero que también le parece una raíz literaria de imposible poda, y más en el fin de siglo:

En la última vuelta del camino, doña Emilia ha tenido tiempo de afianzar sus impresiones y certezas generadas en torno a la literatura francesa y $[. .$.$] en torno$

${ }_{13}$ Para el desarrollo de la idea de hipotexto romántico, cf. Biruté CiPLIJAUSKAITÉ, «El romanticismo como hipotexto en el realismo», en Y. LISSORGUES (ed.), Realismo y naturalismo (cit.), pp. 90-97.

14 «Emilia Pardo Bazán and the Phenomenon of French Decadentism», Publications of the Modern Language Association, 81 (oct. 1966), p. 420.

15 «La recepción crítica de Le Docteur Pascal» (cit.), p. 129.

16 «Emilia Pardo Bazán: entre el Romanticismo y el Realismo», en Luis F. Díaz Larios y Enrique Miralles (eds.), Actas del I Coloquio de la Sociedad de Literatura Española del Siglo XIX. "Del Romanticismo al Realismo» (Barcelona, Universidad, 1998), pp. 437-38. 
a su novela. [...] Llaman la atención las proporciones que alcanza en su visión teórica la consideración crítica del romanticismo, movimiento que es ahora contemplado con menos reticencias, para ponderar su decisiva importancia en la redención del género. Nunca hasta este momento había sentido explícitamente la necesidad de velar sus armas de novelista ante el altar romántico, y ello a pesar de haber manifestado siempre en torno a él un sentimiento mezclado de admiración y rechazo ${ }^{17}$.

Modernismo, romanticismo, decadentismo, sensibilidad finisecular... ¿Parte todo ello del «componente del hipotexto romántico [que] aflora por estos años en el universo narrativo pardobazaniano», y que está «presente no solo en gran parte de su creación, sino también en sus planteamientos teórico-críticos» ${ }^{18}$ ?

Pardo Bazán va viendo la luz, y lo que escribe en estos años finiseculares está cortado por el mismo patrón. Como señaló en su momento Walter T. Pattison, sus novelas de este tiempo, El saludo de las brujas, la inacabada El niño de Guzmán (1898) y Misterio (1903), «have a common note in their escapist tendency» ${ }^{19}$. Y esta, el escapismo, es la tendencia a la que se inclina decididamente la última Pardo Bazán.

El cambio de siglo le da la respuesta buscada en los años posteriores a su despego del naturalismo. En La quimera (1905) son perceptibles claramente los ecos del modernismo, ecos quizá avanzados por Pardo Bazán años atrás, como ha apuntado Hemingway ${ }^{20}$. Es curiosa la notable atención prestada en los últimos años a esta novela, objeto, incluso, de libros monográficos ${ }^{21}$. La quimera dicta la lección de que el refinamiento es el medio de superar una realidad que el artista repudia. La importancia del mundo artístico en este y otros relatos últimos de Pardo Bazán justifica la aplica-

17 Cristina PATIÑo EIRÍn, Poética de la novela en la obra crítica de Emilia Pardo Bazán, Santiago de Compostela, Universidad, 1998, p. 279.

${ }^{18}$ Ibíd., p. 199 y n. 51. La misma autora afirma en otro lugar que, «aunque son contradictorias muchas veces las relaciones que con el pensamiento romántico mantiene Pardo Bazán (como es dual Zola), resulta un hecho constatable a lo largo de su dilatada trayectoria de polígrafa el de su despego de la novela escrita durante aquel período» [«Émile Zola en la obra teórico-crítica de Pardo Bazán (1879-1886)», en S. SAILlard y A. Sotelo VÁzQuez (eds.), Zola y España (cit.), p. 123, n. 3]. Analizando El Cisne de Vilamorta, E. PENAS alude también al antirromanticismo de Pardo Bazán: «La autora coruñesa desaprueba dogmas fundamentales del movimiento romántico»; «el héroe romántico, el poeta becqueriano es ridiculizado con frecuencia en muchas de sus acciones» [ «El Cisne de Vilamorta, de Emilia Pardo Bazán, y los modelos literarios», en J. M. GonZÁlez Herrán (ed.), Estudios sobre Emilia Pardo Bazán (cit.), p. 288].

${ }_{19}$ Emilia Pardo Bazán, Nueva York, Twayne, 1971, p. 84.

20 «Sensibilidad decadentista en el realismo español: el caso de Un viaje de novios», en Y. LISSORGUES (ed.), Realismo y naturalismo (cit.), pp. 226-36.

${ }^{21}$ Daniel S. WhITAKeR, «La quimera» de Pardo Bazán y la literatura finisecular, Madrid, Pliegos, 1988; Magdalena AguinAGA ALFONSO, «La quimera». Orientación hacia el misticismo, La Coruña, Do Castro, 1993. 
ción a ellos de modernas metodologías críticas como la ekphrástica, en cierto modo evocada por Yolanda Latorre Ceresuela:

Apoyada en numerosos pintores españoles o extranjeros practica en sus relatos de madurez lo que se denomina, y ella misma denominó, «transposición artística» [...], cuyos recursos retóricos quedaron plasmados en sus «novelas de artista», género narrativo que recoge la problemática de un héroe-creador ${ }^{22}$.

Chad C. Wright ha sugerido también una interpretación que relaciona, como hace la ekphrasis con las artes plásticas, la literatura y otras formas estéticas, en este caso la música. El vínculo es pertinente si consideramos la situación del arte musical en el momento en que La quimera se publica:

Puede compararse con La valse, la pieza de música escrita por Ravel, [pieza que] es una celebración del vals vienés que simbolizaba el orden y la estabilidad de una época (el siglo XIX) que se estaba desvaneciendo $\mathrm{y}$, al mismo tiempo, representaba las tonalidades y la forma de la nueva música del siglo $\mathrm{XX}^{23}$.

A los ecos modernistas se suman en La sirena negra (1908) los de la filosofía pesimista de Schopenhauer y la irracionalista de Nietzsche. El pensamiento de La sirena negra es la confusa amalgama esperable en quien sigue tanteando posibilidades, buscando un camino que le permita volver al punto de origen ${ }^{24}$. Como ha escrito J. Vidal Solanas:

La filosofía de Schopenhauer, el budismo, el cristianismo tradicional: conjunto confuso de ideologías y de experiencias personales de la autora que en forma vertiginosa se filtran en la novela, produciendo en el ánimo del lector el interés, pero también la confusión ${ }^{25}$.

«Tan deleznable, tan mísero» es el mundo..., a juicio del protagonista de La sirena negra (cap. 7). Ya no es la naturaleza la que impone su ley (si es que alguna vez lo hizo en el mundo de Pardo Bazán), sino el alma, palabra esta repetida en el curso de una novela cuya lección ideológica viene dada por la siguiente frase: «La solución de la vida material carece de importancia; que el dolor está más adentro» (cap. 10).

\footnotetext{
22 «Emilia Pardo Bazán hacia el siglo XX: la estetización pictórica», en J. M. GoNZÁlez HERrán (ed.), Estudios sobre Emilia Pardo Bazán (cit.), p. 197.

${ }^{23}$ «Pastel / pastelista / pastelero: un ejemplo de antanaclasis [punning] en La quimera», en ibíd., p. 378.

${ }^{24}$ La valoración que Guillermo DE TORRE hacía de La sirena negra fue muy positiva: «Aquí, sí, la autora recobra su dominio, su maestría, y la extraña atmósfera trágica que flota en el libro se trasmite al lector con autenticidad emotiva» (Del 98 al Barroco, Madrid, Gredos, 1969, p. 261).

${ }^{25}$ «Estructura y temática en La sirena negra», Revista de Estudios Hispánicos, 9 (en. 1975), p. 79. La novela es, efectivamente, «fruto de la imaginación de una romántica rezagada» (ibíd., p. 80).
} 
Es justificado, teniendo en cuenta aseveraciones como la anterior, el interés que a estudiosos como Porfirio Sánchez y M. Hemingway ha merecido esta novela desde el punto de vista religioso. Si el primero señalaba que «los dos amores de Gaspar de Montenegro son verdaderos ejemplos de amor místico, porque reflejan genuinas y auténticas experiencias místicas, la primera con la sirena negra y la segunda con Dios» ${ }^{26}$, el segundo ha matizado que «what is presented in Pardo Bazán's last novels is a specifically Catholic alternative to the decadent ideal, specifically Catholic, in a Western context, because centred on the Communion of Saints» ${ }^{27}$.

Este punto de la trayectoria de la novelista ejemplifica con claridad la de todo un movimiento. Preguntémonos, por ejemplo, qué ha cambiado desde 1883 (La Tribuna) hasta 1908. En este cuarto de siglo España ha perdido sus posesiones ultramarinas y se han agudizado los problemas sociales, todo ello al mismo tiempo que el escritor naturalista se pasa a las filas del espiritualismo o el decadentismo, sin que el tratamiento de los temas colectivos en su literatura experimente modificaciones sustanciales. Los desfavorecidos de La Tribuna no se rebelaban, es cierto, pero sí expresaban sus quejas. Los de La sirena negra llegan a agradecer la caridad de quienes la ejercen, hasta el punto de adorar a su benefactor como si de un dios se tratara. La escritora en otro tiempo interesada por el naturalismo ahora se nos muestra desengañada y desesperanzada acerca de las posibilidades de transformación social, y por ello opta por refugiarse en la intimidad y olvidar el entorno. Le sucede a Pardo Bazán, pero también a Galdós, a Clarín y, en cierto modo, a Blasco Ibáñez, aunque más tardíamente. El análisis, partiendo de una novela como La sirena negra, podría llevarse más lejos y acentuar la lectura pesimista, porque aquel determinismo zoliano ha devenido fatalismo decadentista. Es la evolución sintetizada por Gonzalo Sobejano:

Hacia 1880, con el naturalismo, se había exaltado la VERDAD de la razón y de la ciencia. Pocos años después, hacia 1890, se aspira a completar esa insuficiente verdad, y a moderar su arrogancia, enalteciendo la BONDAD del espíritu voluntarioso y caritativo. Y casi al mismo tiempo - aunque en España con resultados que no alcanzarían volumen hasta 1900 - se ensalzaría finalmente la BELLEZA de las sensaciones y del arte ${ }^{28}$.

\footnotetext{
26 «La dualidad mística en La sirena negra de Pardo Bazán», Hispania, 53 (mayo 1970), p. 195.

27 «The Religious Content of Pardo Bazán's La sirena negra», Bulletin of Hispanic Studies, 49 (1972), pp. 380-81. El propio HEMINGWAY ha profundizado en las claras connotaciones religiosas de la obra de Pardo Bazán [cf. su artículo «Grace, Nature, Naturalism, and Pardo Bazán», Forum for Modern Language Studies, 16 (oct. 1980), pp. 341-49].

${ }^{28}$ «La quiebra del naturalismo en la literatura española del final del siglo», en L. ROMERO TOBAR (ed.), El camino hacia el 98 (cit.), p. 14.
} 
La última novela de Pardo Bazán, Dulce Dueño (1911), abraza con todas sus consecuencias el decadentismo. La Lina del presente narrativo es la Catalina del pasado, y el tema a discusión, idéntico en todo tiempo: la búsqueda del amor y la belleza, y la importancia de la religión en ese contexto indagatorio. Otra vez la circunferencia se cierra: aquella época coincide con esta en su interés por el lujo y el misterio. Dios proporciona el consuelo que ningún dato terrenal está en condiciones de dar al ser humano. Poco importará a la protagonista que la sociedad la condene a la reclusión en el manicomio, porque ella se siente atada a su Dueño ${ }^{29}$. El proceso ha llegado a su fin: los últimos libros de Pardo Bazán no son pasos sucesivos en una hipotética búsqueda, sino progresivos afianzamientos de unas raíces que poco tenían de naturalistas. Aunque tardíamente, Pardo Bazán encontraba para su literatura ese mundo estable del que nunca desearía haberse apartado ( $y$, en el fondo, si se examina atentamente la cuestión, nunca lo hizo) ${ }^{30}$.

Por aquellos mismos años Vicente Blasco Ibáñez, el escritor que, de entre los más significados, se conceptuaba entonces como representante español de un naturalismo no atenuado ${ }^{31}$, optaba decididamente por ganar-

\footnotetext{
${ }^{29}$ La actitud de Lina sugiere, para Carole A. BRADFORD, «a desire to remain alienated from the world, to avoid confrontation with reality» [«Alienation and the Dual Personality in the Last Three Novels of Emilia Pardo Bazán», Revista de Estudios Hispánicos, 12 (oct. 1978), p. 416].

${ }^{30}$ El sintagma «naturalismo católico», que ha sido utilizado, por ejemplo, por Gifford DAvis [«Catholicism and Naturalism: Pardo Bazán's Reply to Zola», Modern Language Notes, 90 (mar. 1975), p. 283], y que ha hecho fortuna en la crítica sobre Pardo Bazán, admite variantes como «naturalismo atenuado» [Robert M. SCARI, «El naturalismo atenuado de Morriña», Revista de Ideas Estéticas, n. 120 (oct.-dic. 1972), pp. 273-83]. Esta frase de M. GoRDON BROWN, escrita hace más de medio siglo, resume una idea ampliamente difundida entre los estudiosos: «El ideal de doña Emilia era más bien de un naturalismo intermedio, transicional, entre el irrealismo romántico y el verismo» [ «La condesa de Pardo Bazán y el naturalismo», Hispania, 31 (mayo 1948), pp. 152-66]. Esta otra de María Guadalupe GARCÍA BARRAGÁN también sintetiza una idea generalizada: «El realismo naturalista de Emilia Pardo Bazán [...] es un naturalismo atenuado, menos crudo y brutal, menos determinista y científico que el francés» [«Emilia Pardo Basán [sic]. Algo más en torno a su naturalismo y feminismo», Cuadernos Americanos, n. 222 (en.-feb. 1979), p. 190]. A similares planteamientos tradicionalistas responde el artículo de Emilio GONZÁLEZ LÓPEZ «Doña Emilia Pardo Bazán y el naturalismo español en la narrativa», Sin Nombre, 7 (1976), pp. 62-67.

${ }^{31}$ Idea que, en realidad, ya fue cuestionada por sus contemporáneos. Camille PITOLLET ponía el dedo en la llaga incluso antes de la muerte del escritor valenciano, al afirmar que «l'influence exercée sur Blasco Ibáñez par l'œuvre d'Émile Zola constitue un problème que ne résolvent pas de simples affirmations» [V. Blasco Ibáñez. Ses romans
} 
se al público internacional con argumentos cosmopolitas desarrollados en trasatlánticos o ciudades no españolas. El ciclo de novelas sociales, o de tesis, o de naturalismo radical desarrollado entre 1903 y 1905 (La catedral, El intruso, La bodega y La horda) había concluido. En realidad, este bloque político puede considerarse más un paréntesis que una fase en la evolución de Blasco Ibáñez ${ }^{32}$. En alguna de sus novelas valencianas ese decadentismo finisecular que rastreamos como derivación última de una facción de nuestro naturalismo había asomado con claridad. La Leonora de Entre naranjos (1900) presenta todas las notaciones propias del caso: aburrida de la existencia y necesitada de nuevas emociones, es más literatura que realidad. El mundo de Entre naranjos está dominado por la sensualidad casi modernista, pero esta se da la mano con el hipotexto romántico,

et le roman de sa vie, París, Calmann-Lévy, (1921), p. 196). Poco después, en 1923, Katherine REDING afirmaba que «a 'comparative study of the two [Blasco Ibáñez y Zola] reveals fundamental differences in their artistic conceptions as well as in their naturalistic technique» [«Blasco Ibáñez and Zola», Hispania, 6 (dic. 1923), p. 365]. En 1928 Eduardo ZAMACOIS negaba el naturalismo de Blasco, y solo se mostraba dispuesto a admitir que Arroz y tartana estuviera «escrita bajo la sugestión, legítimamente obsesionadora, del autor de Germinal» (Vicente Blasco Ibáñez, Madrid, La Novela Mundial, año III, 19 feb. 1928, p. 87). Dentro aún de la misma década, Ramón MARTínEZ DE LA RIVA escribía: «Ni aun en la obra de las primeras épocas de Blasco puede afirmarse que este fuera influenciado intensamente por el autor de El vientre de París, si no es en algunos aspectos descriptivos» (Blasco Ibáñez. Su vida, su obra, su muerte, sus mejores páginas, Madrid, Mundo Latino, 1929, p. 107). Lo que contrasta con el taxativo (y fundado en el tópico, sin análisis literario de por medio) juicio del biógrafo de Blasco Ibáñez, J. L. LEÓN ROCA: «Toda su obra está pensada y ejecutada en Zola» (Vicente Blasco Ibáñez, Valencia, s. i., ${ }^{4} 1990$, p. 253 ). La crítica más próxima a nuestros días se manifiesta distanciada de esta idea. Así, Paul SMITH considera que «en sus mejores novelas los personajes actúan y piensan en función del medio ambiente. Sin embargo, el autor no sigue la técnica naturalista de la abundante y cuidadosa documentación con pretensiones científicas» (Vicente Blasco Ibáñez: una nueva introducción a su vida y obra, Santiago de Chile, Andrés Bello, 1972, pp. 42-43). Y también A. Grove DAY y Edgar C. KNOWLTON, jr.: «By the usual standards of Naturalism [...] Blasco was far from being a card-carrying of this important school» (V. Blasco Ibáñez, Nueva York, Twayne, 1972, p. 132). En las páginas 29-32 y 157-64 (apéndice II) del libro de Christopher L. ANDERSON Primitives, Patriarchy, and the Picaresque in Blasco Ibáñez's «Cañas y barro» (Potomac, Scripta Humanistica, 1995) puede encontrarse un resumen de las opiniones críticas sobre la relación entre el autor valenciano y el naturalismo. Más recientemente, Santiago RENARD ha aceptado el naturalismo de las novelas valencianas [«El discurso del otro en Blasco Ibáñez. Adaptación y crisis del naturalismo», en S. SAILlARD y A. Sotelo VÁzQuez, Zola y España (cit.), pp. 139-45].

${ }^{32}$ El comentario de Jeremy T. MEDINA tiene su punto de apropiada crueldad: «We have no doubt but that his compassion for the plight of the pueblo and his desire for its eventual emancipation were genuine», pero... «after the publication of the novels of thesis, the author continue to decry the oppresion of the common people. But, we must add, he also continued to ride to the Montecarlo Casino in his luxurious automobile» (From Sermon to Art. The Thesis Novels of Vicente Blasco Ibáñez, Valencia, Albatros-Hispanófila, 1998, p. 87). 
más que visible en la psicología del personaje femenino ${ }^{33}$, repetido, con variantes, en novelas posteriores: La maja desnuda $(1906)^{34}$, Sangre y arena (1908) y La voluntad de vivir, cuyos ejemplares destruyó el autor después de escribirla en 1907.

El título de esta última, con la que se cierra el ciclo abierto por Entre naranjos, permite identificar una de las fuentes del Blasco Ibáñez nacido con el nuevo siglo: un Schopenhauer cuyas ideas ya se intuían en Entre naranjos $^{35}$. En cualquier caso, la mezcla de influencias visible en el Blasco Ibáñez de estos años sigue dejándose notar: modernismo, pero también folletín y novela de aventuras.

Los estudios más recientes acerca de la obra de Blasco Ibáñez se han centrado precisamente en la sensibilidad modernista de sus páginas, aunque no sea fácil llegar a un acuerdo sobre cuestiones terminológicas. Por ejemplo, Aída E. Trau afirma que «no, cabe duda de que en cuanto a su literatura fue uno de los primeros d'Annunzianos en España» ${ }^{36}$, pero Jeffrey Thomas Oxford prefiere llamarlo «post-Romantic» ${ }^{37}$, como paso previo a la exposición de sus dudas sobre el naturalismo del autor:

His procedures $[\ldots]$ are frequently more consistent with the practices of Romanticism and post-Romantics (especially as concerns the «pathetic fallacy» and variants there of) than with those of objective Naturalism ${ }^{38}$.

Es cierto que se sigue hablando del naturalismo de Blasco Ibáñez ${ }^{39}$. Pero los investigadores más próximos a nuestros días se interesan en mayor medida por su modernismo. La obra del escritor valenciano es un tronco muy ramificado, y no parece que existan ya motivos suficientes para considerar que la derivación naturalista es la más relevante. En una carta a

33 «Entre naranjos es la más romántica y menos naturalista de las novelas valencianas» (Rafael SosA, Vicente Blasco Ibáñez a través de sus cuentos y novelas valencianas, Madrid, Playor, 1974, p. 125).

${ }^{34}$ Cf. J. T. Medina, The Psychological Novels of Vicente Blasco Ibáñez, Valencia, Albatros-Hispanófila, 1990. En su artículo «De Zola à Blasco Ibáñez en passant par Goya» [en S. Saillard y A. Sotelo VÁzquez (eds.), Zola y España (cit.), pp. 205-12], AnneMarie REBOUL muestra las analogías entre esta novela y alguna obra de Zola.

${ }^{35}$ En su introducción a la reciente edición de La voluntad de vivir, Facundo TOMÁs afirma que esta novela, «al igual que La voluntad de Martínez Ruiz, es una ficcionalización del pensamiento de Arthur Schopenhauer» (Madrid, Cátedra, 1999, p. 122).

${ }^{36}$ Arte y música en las novelas de Blasco Ibáñez, Potomac, Scripta Humanistica, 1994, p. 35 .

${ }^{37}$ Vicente Blasco Ibáñez. Color Symbolism in Selected Novels, Nueva York, Peter Lang, 1997, p. 9.

${ }^{38}$ Ibíd., p. 11.

${ }^{39}$ Por ejemplo, en los capítulos 4 y 5 del libro de Richard A. CARDwELl, Blasco Ibáñez. "La barraca», Londres, Grant \& Cutler, ${ }^{2} 1994$. Pero debe tenerse en cuenta que se trata de una nueva edición de un libro ya antiguo. 
Julio Cejador fechada en 1918, Blasco Ibáñez marcaba una distancia considerable con respecto a Zola, a la vez que aclaraba deudas reconocidas:

Yo, en mis primeras novelas, sufría de modo considerable la influencia de Zola y de la escuela naturalista, entonces en pleno triunfo. En mis primeras novelas nada más. [...] Forzosamente debía empezar yo imitando a alguien, como todos, y me place que mi modelo fuese Zola, mejor que otro anodino. Zola, por querer ser jefe de escuela, fue un exagerado que buscó, muchas veces a sabiendas, irritar al público, acariciándolo a contrapelo. [...] Cuando publiqué mis primeras novelas, las encontraron semejantes a las obras zolescas, y me clasificaron para siempre. [...] Yo, para muchos, escriba lo que escriba, y aunque sufra mi existencia literaria las más radicales evoluciones, siempre seré «el Zola español». Los que tal dicen y repiten por perezoso automatismo demuestran no conocer ni a Zola ni a mí, o, a lo menos, si conocen las obras de ambos, las han leído de corrido, sin comprenderlas ${ }^{40}$.

En 1918, pues, nuestro novelista se siente muy lejos ya de sus coqueteos con el naturalismo. Su apuesta es otra muy distinta, y su desvío no deja lugar a dudas:

Reconozco que ahora, en plena madurez, me quedan muy pocos puntos de contacto con mi antiguo ídolo. Apoyó Zola toda su obra principalmente en una teoría científica, la de la herencia fisiológica, y esta teoría, al derrumbarse en parte, se ha llevado detrás las afirmaciones más graves de su labor intelectual, toda la armazón interior de sus novelas. En la actualidad, por más que busco, encuentro muy escasas relaciones con el gran novelista que fue considerado como mi padre literario. Ni por el método de trabajo, ni por el estilo, tenemos la menor semejanza ${ }^{41}$.

Hasta al menos 1914, año en que, después de varios viajes y el abandono de su activismo político, Blasco Ibáñez se instala en París, su narrativa es una confluencia de hipotextos y tendencias, incluida la novela de tesis (La araña negra, primera que publicó, en 1892), pero excluida cualquier veleidad espiritualista. Oxford lo ha señalado, al indicar que «Blasco Ibáñez never fully overcome a certain residual Romantic tendency of his early folletín writings» ${ }^{42}$. También reciente es este resumen de María José Navarro:

Naturalista seguidor de Zola en sus primeras novelas; naturalista combativo en sus novelas sociales, coetáneo de la Generación del 98 y los modernistas, Blasco fue atravesando todas las etapas de la vida literaria del país sin ser asimilado por ningún programa común ${ }^{43}$.

${ }^{40} \mathrm{El}$ texto puede leerse, por ejemplo, en el libro de Pilar TorTosa Domingo, Blasco Ibáñez. La mejor novela, su vida (Valencia, Foro, ${ }^{2} 1998$ ). La cita, en pp. 338-39.

${ }^{41}$ Ibíd.

${ }^{42}$ Vicente Blasco Ibáñez (cit.), p. 90.

43 «Introducción» a V. BLASCO IBÁÑ̃E, Mare Nostrum (Alicante, Instituto de Cultura Juan Gil-Albert, 1994), p. 65. 
El hipotexto del folletín, por ejemplo, se superpone a cualesquiera otros en la historia del torero triunfador de Sangre y arena. A partir del año señalado, la elección de Blasco Ibáñez es más acorde con el siglo Xx: el cosmopolitismo (Los argonautas, de 1914, Los cuatro jinetes del Apocalipsis, de 1916, y Mare Nostrum, de 1918), el simbolismo (El paraíso de las mujeres, de 1922), el historicismo (El Papa del mar, 1925). De los catorce cuentos incluidos en El préstamo de la difunta (1921), cinco están ambientados en Hispanoamérica, y la mayor parte del libro tiene como fondo la reciente guerra mundial. El naturalismo era ya solo recuerdo (plagio para algunos ${ }^{44}$ ), y había llegado el momento de administrar lo recaudado por libros como Los cuatro jinetes del Apocalipsis, cuyas ediciones estadounidenses se sucedían a un ritmo de vértigo que cualquier colega español habría, sin duda, envidiado.

Las dos trayectorias diseñadas, la de Pardo Bazán y la de Blasco Ibáñez, coinciden en distanciarse de la concreción tan cara al naturalismo. Blasco se aventura por mundos lejanos; Pardo se olvida de lo exterior al yo y vuelve sus ojos al misterio de la interioridad y a la fe religiosa, asidero último e irrenunciable.

\section{IV}

El caso de José Ortega Munilla es distinto ${ }^{45}$. Aunque nunca escribió una novela enteramente naturalista, incluyó en varias de ellas elementos próximos al mundo de Zola, incluso antes de la aparición de La desheredada. Bastará recordar ese capítulo de Lucio Tréllez (1879) en que la descripción de los suburbios madrileños desciende a detalles reminiscentes de las teorías de Zola; o el objetivismo planteado como aspiración teórica en Cleopatra Pérez (1884) e Idilio lúgubre (1887). Aún más significativa, en fin, puede resultar la alusión al «gran Claudio Bernard» inserta en el prólogo de Don Juan Solo, una novela publicada en 1880, antes, por consiguiente, de la aparición oficial del naturalismo en España. Aunque quizá, como ha señalado Ruth Schmidt,

el rasgo Naturalista que aparece con más persistencia en las obras de Ortega Munilla, especialmente en su primer período, de 1879 a 1884 , pero también a

44 Jeanine MODAVE escribió un artículo dedicado a demostrar que partes concretas del ciclo valenciano (Arroz y tartana, Sónnica la cortesana) eran copia directa de textos de Zola, Flaubert y Pierre Louys; cf. «Blasco Ibáñez et le naturalisme français», Les Lettres Romanes, 12 (ag. 1958), pp. 287-301.

45 Jacinto Octavio Picón no es analizado aquí, por las razones que expongo en mi artículo «Dulce y sabrosa, de Jacinto Octavio Picón: la vía esteticista hacia la novela galante» [Cauce (Universidad de Sevilla), n. ${ }^{\circ} 16$ (1993), pp. 177-91], artículo resumido en Salina (Universidad de Tarragona), n. 7 (dic. 1993), pp. 59-62: «Centenario de la publicación de Dulce y sabrosa, de Jacinto Octavio Picón: ¿novela antinaturalista?». 
lo largo de su producción novelística, es el pesimismo. De sus dieciséis novelas y novelas cortas, únicamente dos tienen un final feliz, al menos para alguno de sus personajes. Los demás terminan trágicamente ${ }^{46}$.

Lo cierto es que, como de costumbre en nuestros narradores naturalistas no radicales, la teoría y la práctica no andan a la par en las páginas de Ortega Munilla. La falta de una novela auténticamente naturalista se compensa, como en otros casos, con un discurso fiel a Zola. El discurso de, por ejemplo, estas palabras suyas: «Hay que ser naturalista o no ser nada», porque decir «gentes refractarias al naturalismo»es, según él, decir tanto como «refractarias a la verdad» 47 .

De sus novelas medianamente apreciables quizá sea la mejor El paño pardo. A diferencia de otros autores, Ortega Munilla mantenía en 1914, fecha de la publicación de la obra, una cierta fidelidad al naturalismo, en años en que sus antiguos practicantes lo habían ya abandonado. Esos conflictos sociales latentes que habían terminado esquivando Pardo Bazán y Blasco Ibáñez son precisamente los que nutren el argumento de El paño pardo, enlazando con la revisión de la España profunda que por entonces estaba dando a conocer el que tal vez podamos denominar segundo naturalismo español, el de escritores como José López Pinillos, Felipe Trigo y Eugenio Noel. De esta forma, el naturalismo de hacia 1885 conecta con el de hacia 1920, y lo hace a través de un autor que vive las dos épocas y que de las dos obtiene materia novelable ${ }^{48}$.

\section{V}

En este panorama general, la obra de Armando Palacio Valdés tiene una importancia singular, dada la longevidad del autor, que empieza a publicar novelas coincidiendo con el nacimiento del naturalismo español (1881: El señorito Octavio), y que muere nada menos que en 1938. Tal vez en ningún escritor sesentayochista se transparente con más claridad el hipotexto romántico: sus personajes femeninos leen folletines (en lo que coinciden, naturalmente, con otros muchos de la novela realista), y la música

${ }^{46}$ Ortega Munilla y sus novelas, Madrid, Revista de Occidente, 1973, pp. 186-87.

${ }^{47}$ Los Lunes del Imparcial, 20 feb. 1882.

${ }^{48}$ El nexo entre el naturalismo de los años ochenta del siglo XIX y el segundo naturalismo lo apuntó no hace demasiado tiempo Miguel Ángel LOZANO MARCO [«Un aspecto del naturalismo español: de las novelas médico-sociales de Eduardo López Bago a Felipe Trigo», Montearabí (Yecla), n. ${ }^{\circ} 1$ (1986), pp. 29-40]. En realidad, se había apuntado tiempo atrás, aunque fuera con interpretaciones tan curiosas como la de Francisco M. BERGASA GONZÁLEZ: «Abandonado de todos, el naturalismo degeneró, primero, en un erotismo grosero, en la obra de Blasco Ibáñez, y, más tarde, en el estilo pornográfico de Trigo, Mata, Hernández Catá, Francés, «Colombine», etc.» [«La Pardo Bazán y el naturalismo», La Estafeta Literaria, n. 295 (4 julio 1964), p. 6]. 
(romántica, claro está) ambienta una buena parte de sus actos y pensamientos. Lo ha precisado Guadalupe Gómez Ferrer:

En su obra se hallan presentes multitud de motivos románticos. Junto a la realidad incorporada tanto en ambientes como en personajes, y junto a los recientes procedimientos científicos adoptados, es innegable que en la obra del autor asturiano - sobre todo en la de sus primeros años- encontramos numerosas pervivencias románticas que se plasman en impulsos líricos, en estados sentimentales, en situaciones melodramáticas, en la contextura de algunos personajes e incluso en determinadas secuencias novelescas ${ }^{49}$.

Las contradicciones que acompañaron toda la discusión sobre el naturalismo (del que, por cierto, se habla en La espuma, de 1890) asoman también en sus novelas: por ejemplo, el protagonista de La hermana San Sulpicio (1889) se declara contrario al «grosero naturalismo», pero ese mismo libro incluye una extemporánea escena naturalista.

En las primeras novelas (El señorito Octavio o El idilio de un enfermo, de 1884), el retrato del hombre del campo no llegaba a las tintas negras del Zola más radical, el de La tierra, por ejemplo. Pero los trazos eran lo suficientemente gruesos como para pensar en una cierta dependencia del naturalismo. La situación ha cambiado, y mucho, en la España de 1893, año en que Palacio Valdés ha abrazado ya la causa de un espiritualismo no muy distante del que había elegido como opción literaria y existencial Pardo Bazán ${ }^{50}$. Como Galdós aproximadamente por esos mismos años, en la década de los ochenta Palacio Valdés busca su camino: José (1885), Riverita (1886), Maximina (1886), La hermana San Sulpicio son las estaciones de un viaje que culmina, tras el paréntesis impuesto por La espuma (1890), en El origen del pensamiento, publicada en 1893, cuando el naturalismo comenzaba a ser desplazado en España.

Palacio Valdés ridiculiza en la figura del Pantaleón Sánchez de esta última novela el positivismo experimental, a lo último recluido en un manicomio ${ }^{51}$. La lección ideológica es clara: el origen del pensamiento no

${ }^{49}$ Palacio Valdés y el mundo social de la Restauración, Oviedo, Instituto de Estudios Asturianos, 1983, p. 89.

50 José M. ${ }^{a}$ RoCA FRANQUESA, sin embargo, traza la línea divisoria entre 1896 y 1899 : «En la obra de Palacio Valdés se pueden señalar dos épocas perfectamente delimitadas, y caracterizadas por un proceso de revalorización moral hasta llegar a una exposición cristiana de la vida. El punto crucial de estas dos épocas hay que situarlo entre 1896, fecha de publicación de Los majos de Cádiz, y 1899, año en que aparece La Alegría del Capitán Ribot" (Palacio Valdés: técnica novelística y credo estético, Oviedo, Instituto de Estudios Asturianos, 1951, p. 47). En 1899, Palacio Valdés confesaba a Clarín: «Me he convertido sincera y absolutamente al cristianismo» (el texto se puede leer en el libro citado).

${ }_{51}$ «En el fondo la novela es una rechifla de la frenología, una sorda e implacable ironía disparada contra la frenología, la antropometría, la psiquiatría y de [sic] positivismo lombrosiano - muy en boga como última palabra de la ciencia experimental一» 
está en la ciencia, sino en una armonía universal probablemente establecida por Dios (aunque, bien es cierto, no se le menciona). Admitido este giro, la relativa dureza de El maestrante, también publicada en 1893, es achacable no a un naturalismo que ya comenzaba a plegar velas, sino al hipotexto del folletín.

El tránsito de siglo confirma una evolución similar a la experimentada por sus compañeros de generación. Como hizo Pardo Bazán en El saludo de las brujas, Palacio Valdés mira muy atrás en el momento de escribir una novela tan arcaica como Los majos de Cádiz (1896). Y en el desenlace de La alegría del capitán Ribot (1899) triunfa ya el idealismo platónico del amor puro, desprovisto del grosero prosaísmo fisiológico propio del naturalismo más extremo ${ }^{52}$.

La aldea perdida (1903) se inicia con un canto a la utopía arcádica: los habitantes del campo viven en una inconsciente felicidad hasta que se injerta en su hábitat el pertúrbador elemento externo procedente de la industrialización. Si Galdós y Pardo Bazán se habían refugiado por entonces en el yo, Palacio Valdés lo hacía (o intentaba hacerlo) en el incontaminado ámbito rural.

Una de sus últimas obras es Los cármenes de Granada (1927). Es el año en que una brillante generación poética ha saltado a la palestra, y casi el preludio de graves acontecimientos políticos y sociales. Pero un hombre del siglo XIX, como evidentemente lo es Palacio Valdés, no puede ya incorporarse a ese proceso de cambio. En consecuencia, nada más lógico que la idealización que el protagonista, Alfonso, propone como proyecto de vida: romántico rezagado, querría para su existencia la emoción que su novia es incapaz de proporcionarle. Una joven a la que conoce en la Alhambra parece encarnar esas ansias de aventura. Pero su matrimonio con ella fracasa, porque la figura femenina es una superchería. Palacio Valdés deja sin contestar la pregunta de si la teoría idealista le parecía aún válida nueve años antes de la guerra civil, o si soñar la vida, como hicieron los románticos, es un principio ideal destinado a la frustración porque, a fin de cuentas, es la realidad la que se impone ${ }^{53}$. Cualquiera que fuese la respuesta, no quedaría muy alejada de las de otros autores de su grupo generacional.

(Andrés GonZÁlez Blanco, Armando Palacio Valdés. Juicio crítico de sus obras, Madrid, La Novela Corta, n. ${ }^{\circ} 237$ (10 jul. 1920), s. p.).

${ }^{52}$ No en vano Gilbert PAOLINI ha podido titular su artículo sobre esta novela «Palacio Valdés y el naturalismo ideal en La alegría del Capitán Ribot» [Letras Peninsulares, V/2.1 (prim. 1989), pp. 19-29]. En un artículo posterior sobre la misma novela señala que en ella se defiende «una renovación y un mejoramiento del ser humano» [«Inquietudes éticas de los escritores de fin del siglo diecinueve», en L. F. DíAZ LARIOS y E. Miralles (eds.), Actas del I Coloquio de la Sociedad de Literatura Española del Siglo XIX (cit.), p. 115].

${ }^{53}$ La hagiografía de Rafael NARBONA elimina cualquier asomo de problematismo en la vida de Palacio Valdés. El título de su libro lo dice todo: Palacio Valdés o la armo- 
Fueron estos los caminos recorridos por algunos de nuestros escritores realistas (más o menos simpatizantes del naturalismo) en su deseo de adaptar la tendencia zolesca a una peculiar forma de sentir la literatura, forma que excluía el exceso. El final del naturalismo español se diferencia del de Zola en el hecho de que este terminó centrando sus esperanzas en un colectivo social, mientras que nuestros autores recabaron los derechos del individuo aisladamente considerado, ya sea sobre la base del pesimismo, ya sea sobre la del misticismo religioso. Incluso cuando, hacia mediados de los ochenta, la novela psicológica comenzaba a dejar atrás el naturalismo de Zola, el escritor francés continuaba reclamando para la ciencia un papel destacado, idea a la que corresponde su producción en los años noventa. Por entonces, ya los escritores españoles más relevantes habían perdido su fe en el progreso y se habían retirado a las posiciones defensivas del yo subjetivo.

Había sido, para algunos, una evolución anunciada. En 1882 E. Gómez Ortiz aventuraba en el tercero de una serie de artículos escritos por él que el naturalismo «dejará [...] de ser la espada amenazadora del buen gusto, corregirá su espíritu haciéndole transigente y comedido» ${ }^{54}$. La divulgación, en torno a 1885 , de la narrativa rusa fue la excusa inmediata para que nuestra novela se distanciara del naturalismo y diese el paso definitivo en el proceso de aproximación a la subjetividad: es esa reconciliación de que habla Walter T. Pattison en su conocido y precursor libro ${ }^{55}$, reconciliación distinta de la bifurcación por la que en esos mismos años optarían autores como, por citar a los dos más conocidos, Alejandro Sawa y Eduardo López $\mathrm{Bago}^{56}$.

nía (Madrid, Librería General de Victoriano Suárez, 1941). Véase este párrafo: «Hay en el escritor, como en el alma de Don Juan, un polarismo manifiesto: un desacuerdo entre su yo y su ser, entre lo ficticio y lo real, entre el artista y el hombre. Este contraste [...] no se dio jamás en Palacio Valdés» (p. 17).

${ }^{54}$ La América, 8 feb. 1882.

${ }^{55}$ El naturalismo español. Historia externa de un movimiento literario, Madrid, Gredos, 1965.

${ }^{56}$ En relación con el primero, es digna de resaltarse la evolución desde el naturalismo a un modernismo inevitablemente romántico. Sawa aporta al naturalismo radical seis novelas publicadas entre 1885 y 1888 . Su viaje a París lo pone en contacto con el simbolismo y, a partir de ese momento, su producción sigue las pautas decadentistas del fin de siglo. Cf. Allen W. PHILliPS, Alejandro Sawa. Mito y realidad (Madrid, Turner, 1976), y Amelina CORREA RAMÓN, Alejandro Sawa y el naturalismo literario (Granada, Universidad, 1993). También Francisco GuTIÉRREZ CARBAJO, «Las teorías naturalistas de Alejandro Sawa y López Bago» [Epos, 7 (1991), pág. 384], y A. CoRrea RAMón, «La coherencia interna en la obra de Alejandro Sawa: del naturalismo al modernismo» [en 
No se vea, sin embargo, en esta evolución un distanciamiento radical de los presupuestos naturalistas que habían orientado la producción intermedia de nuestros escritores. Lo cierto es que dentro de la gran circunferencia romántica que encierra la escritura decimonónica hay alguna otra de carácter más acotado. Por ejemplo, la que une entre sí puntos aparentemente lejanos como lo son el naturalismo espiritual y el discurso de Zola (que no su práctica novelística). Un discurso que a mediados de los ochenta comenzaba a ser examinado con más rigor y, sobre todo, con mayor espíritu crítico.

La simple revisión de rasgos distintivos naturalistas propuesta por Juan Oleza ${ }^{57}$ muestra cómo hay un evidente sustrato moral que, aun siendo muy diferente del que alimenta el discurso de Zola, responde a la misma inquietud reformista. Puntualiza Oleza que el naturalista espiritual se siente apóstol y no científico. Pero Zola también se vio a sí mismo como un apóstol de las nuevas ideas: «Somos, en una palabra, moralistas experimentadores que demuestran por la experiencia cómo se comporta una pasión en un medio social» ${ }^{58}$. Quizá esta coincidencia profunda pueda sustentar la defensa de un concepto, naturalismo espiritual, que a Jacques Beyrie le parece «un verdadero monstruo semántico» ${ }^{59}$.

\section{VII}

En España no faltan ejemplos de naturalismo claramente imbuido de reformismo social y hasta moral, y ello sin necesidad de recurrir a los autores más conocidos, que son, por otra parte, los más renuentes a incluir en sus obras un didactismo explícito. Al maestro de La barraca (1898) dedica Blasco Ibáñez todo un capítulo, de expreso mensaje ideológico. Los lugareños son violentos, casi bárbaros, pero «en el fondo son buena gente. [...] ¿Qué culpa tienen si nacieron para vivir como bestias y nadie les saca de su condición?» (cap. 8). No es la naturaleza la que determina el comportamiento, sino la falta de instrucción, idea no exactamente naturalista, sino

VV.AA., Homenaje al profesor José María Fórneas Besteiro (Granada, Universidad, 1995), p. 123]. Por lo que se refiere a López Bago, desde 1888 o 1889 vive en Hispanoamérica, y cuando retorna a España no vuelve a escribir una novela hasta su muerte, en 1931. La única obra suya recuperada en los últimos tiempos es El separatista, en edición de F. Gutiérrez Carbajo (Madrid, Castalia, 1997).

${ }^{57}$ La novela del siglo XIX. Del parto a la crisis de una ideología, Barcelona, Laia, ${ }^{2} 1984$.

58 «La novela experimental», en El naturalismo (ed. de Laureano Bonet; Barcelona, Península, $\left.{ }^{2} 1989\right)$, p. 48.

59 «A propósito del naturalismo: problemas de terminología y de perspectiva literaria en la segunda mitad del siglo XIX», en Y. LISSORGUES (ed.), Realismo y naturalismo (cit.), p. 43. 
más bien reformista, que Blasco pondrá en boca de otro personaje, el Nacional, de Sangre y arena. Es, bien se ve, un naturalismo tamizado por el cedazo social. Al escritor valenciano no le interesan los problemas de herencia social y física, sino los más evidentes de educación.

Aunque a ellos se han dedicado pocas páginas, son los novelistas menores los que reflejan en España más fielmente el mundo de Zola, quizá porque el mimetismo venía obligado por una capacidad de creación considerablemente menor que la detectable en los grandes autores con los que compartieron tiempo histórico. El prototipo de escritor naturalista puro es López Bago. De su poco estimulante producción cabe subrayar la obsesión por aparecer ante sus numerosos lectores como cruzado de una causa (la naturalista) perseguida por las autoridades. En ningún caso como en este (hecha, claro está, la excepción de Pardo Bazán) la práctica naturalista ha sido complementada con tanta claridad por un discurso específico, aunque en absoluto original.

Tan poco original que se reduce a la transcripción, al final de sus novelas, de páginas de Bernard, el médico en el que Zola encontró sustento científico para sus teorías. Hay, pues, un propósito firme de no desviarse un ápice del discurso inicial de Zola (y de ahí que hable de naturalismo puro, a diferencia del habitual en España). Pero López Bago va más lejos que el escritor francés. Y no para profundizar en el camino abierto por Zola, sino para ensancharlo por sus lados, de tal forma que la novela roce la pornografía y se convierta en un objeto de consumo ${ }^{60}$.

No es seguro que López Bago antepusiera ese espíritu comercial al reformista que animaba el discurso del naturalismo, pero sí es claro que lo situó en un lugar preeminente. No se explica de otro modo su obsesión por informar al lector de todos los procesos judiciales que acompañaban el nacimiento de cada uno de sus libros. López Bago sabía muy bien cuáles eran los procedimientos idóneos para ganar dinero con la novela sin necesidad de abjurar de un reformismo ideológico que servía de eficaz coartada, y los empleó con buena fortuna, si no literaria, sí económica.

El título del ensayo de Pura Fernández es revelador: Eduardo López Bago y el naturalismo radical. La novela y el mercado literario en el siglo $X I X^{61}$. Los datos aportados por la autora son sustanciosos: en menos de dos años, entre octubre de 1884 y agosto de 1886, «se agotan cinco ediciones de La prostituta, seis de La pálida, cinco de La buscona y dos de

60 «Las novelas de López Bago son buena ilustración [...] de las extravagancias a que puede llegar la aplicación sin discernimiento, sin arte, de un naturalismo positivista y mecanicista» [Y. LISSORGUES, «La obra de Emilio Zola como revelador de la singularidad literaria y filosófica española», en S. SAILlard y A. Sotelo VÁZquez (eds.), Zola y España (cit.) p. 73].

${ }^{61}$ Amsterdam-Atlanta, Rodopi, 1995. 
La querida» ${ }^{62}$. Total: 50.000 volúmenes. Incluso si, como hace la propia autora, por aquello de las virtudes propagandísticas de los números voluntariamente hinchados, aceptamos ciertas reservas en relación con esta cifra, la evidencia es incontestable: «El éxito comercial fue absoluto, y si tenemos en cuenta que el precio de cada ejemplar era de tres pesetas, las cantidades obtenidas son fabulosas» ${ }^{63}$.

Por supuesto que la observación sobre la literatura convertida en objeto de consumo se presta a consideraciones múltiples. En una sociedad ya burguesa como lo es la española de la segunda mitad del siglo XIX, el libro ha adquirido el valor comercial que el propio escritor ha deseado para él. Y en este proceso de monetarización el naturalismo, ya desde sus orígenes, se mostraba interesado en adaptarse a las circunstancias.

En efecto, en la génesis de la literatura zoliana hay un embrión de comercialismo: el escritor francés redactó sus primeras obras con una tarifa fija que lo comprometía a entregar al editor diez novelas en cinco años, a cambio de un sueldo previamente establecido. Uno de los textos más divulgados de Zola habla precisamente de «El dinero en la literatura», y en él se lee esta apología del vil metal: «Es el dinero, el beneficio legítimo obtenido con las obras, lo que ha librado al escritor de toda protección humillante [...]. El dinero ha emancipado al escritor, ha creado las letras modernas». Es así como el escritor se convierte en un obrero a destajo: «En la actualidad, nos es necesario producir, producir sin parar. Se trata de la labor de un obrero que debe ganar su pan y que no puede retirarse hasta haber hecho una fortuna» ${ }^{64}$.

Pues bien: el editor español vio pronto en Zola (en Zola, y no en el naturalismo en su conjunto: Germinie Lacerteux, por ejemplo, no se tradujo hasta casi treinta años después de su publicación en Francia) un filón digno de explotarse al máximo. Desde 1885, los libros de Zola aparecieron en nuestro país al mismo tiempo que en el vecino. Ni que decir tiene que detrás de este éxito de público hubo toda una eficaz campaña periodística que dio a conocer en nuestro país no ya los libros que Zola publicaba, sino incluso los que estaba preparando.

Los defensores del naturalismo elevaban a su profeta a los altares mientras que los poco o nada entusiastas de tales excesos no perdían la ocasión de aludir, como lo hacía Menéndez y Pelayo en una carta a Valera fechada el 16 de octubre de 1886, al «sórdido anhelo de ganancia» de Zola y su escuela (idea repetida, por cierto, por el escritor andaluz en el sexto

\footnotetext{
${ }^{62}$ P. 126.

${ }^{63}$ P. 129.

${ }^{64}$ Cf. El naturalismo (cit.), pp. 171 y 174. Jean-François BotRel cita en su artículo «Zola, l'argent et la condition de l'écrivain en Espagne» [en S. SAILlARD y A. SOTELO VÁZQUEZ (eds.), Zola y España (cit.), p. 39] esta ilustrativa frase de Pardo Bazán, fechada en 1909: «Tardé bastante en comprender que escribir pudiese valer dinero».
} 
artículo de sus Apuntes sobre el nuevo arte de escribir novelas). Botrel ha rescatado del olvido (aunque, claro está, solo a manera de ilustrativa enumeración) libros cuyos títulos incitan a la economía de palabras parafrásticas ${ }^{65}$. En carne viva, de varios autores (1885 o 1886), El amor... sin velos (1886), de Manuel Valcárcel, Las mancebas y Las rameras de salón (1891), de Enrique Sánchez Seña, y otros del mismo estilo comparten un detalle significativo: todos, incluso el citado poema de Valcárcel, se adjetivan como naturalistas, como si ello garantizara la atracción de cierto tipo de públi$\mathrm{co}^{66}$.

Botrel centra su interés precisamente en la recepción de tales textos más o menos escandalosos, y siempre con el sexo como reclamo comercial. Pero me parece igualmente importante situar el análisis en el punto de partida; es decir: en el creador que ha perdido de vista la finalidad reformadora del naturalismo y ha subsumido esta en un producto cuyo efecto final sería equivalente al obtenido con aquellas postales que circulaban en la época con el mismo y repetitivo argumento icónico: la mujer ligera de ropas. Dicho de otra forma: la literatura, en este naturalismo radical (y menor), ya no es lo que interesa como elemento primordial.

No cabe duda de que López Bago (y con él, hay que suponer, otros escritores escandalosos menos estudiados que él) lo vio claro desde el primer momento. Basta recordar los títulos de sus delirios narrativos para percatarse de las intenciones más bien prosaicas de quien pensó en ellos: no hay nada como el vil metal para excitar la imaginación de un naturalista radical. En efecto, como recuerda P. Fernández:

Tras el escándalo suscitado por La prostituta [1884], el autor consagra una fórmula literaria que combina, de un lado, el concepto de la creación novelesca como arma de combate ideológico y, de otro, la búsqueda de unos mecanismos narrativos que despierten una ruidosa polémica y muevan al público a consumir masivamente sus obras ${ }^{67}$.

Sentada esa premisa, que poco tiene que ver con la literatura de calidad, y sí mucho con un proceso comercial, únicamente queda discutir si este se antepone siempre al propósito reformista. Creo que incluso en el caso de López Bago sería posible afirmar que la literatura ha dejado de ser un instrumento de reforma social para convertirse en un medio de

${ }^{65}$ Cf. «España, 1880-1890: el naturalismo en situación», en Y. LISSORGUES (ed.), Realismo y naturalismo (cit.), pp. 183-97.

${ }^{66}$ Otros títulos rijosos de los años ochenta: La mujer de todo el mundo (1885), de Alejandro SAWA; La seductora (1887) y Juana Placer (1889), de José DE SILES; La Venus granadina (1888), de R. VEGA ARMENTERO; Trata de blancas (1889), de E. A. FloRES; ¿Pican... pican? (¿1886?), de varios autores.

${ }^{67}$ Eduardo López Bago (cit.), p. 125. 
supervivencia, e incluso algo más ${ }^{68}$. ¿Por qué, si no, López Bago se jacta, en uno de sus característicos apéndices (el de El cura, concretamente), de vivir solo de lo que sus libros le reportan, se envanece de que se vendan tan bien y, en tercer y último lugar, de que gracias a ellos avance la causa naturalista? Catorce novelas escritas y publicadas entre 1884 y 1888 dan fe de esa sujeción del talento creativo a las necesidades económicas. En estos años de efervescencia naturalista es precisamente cuando en España alcanzan su apogeo los libros rijosos citados por Botrel. Aunque se refiera a López Bago, la afirmación de P. Fernández la creo generalizable al naturalismo radical: «Nos encontramos en los aledaños de la denominada cultura de masas [...]: el beneficio se convierte en el principal motor y justificación del proceso de creación» ${ }^{69}$.

Por entonces, lo ideológico había cedido su puesto a otros elementos no exactamente literarios. Acierta Y. Lissorgues cuando asocia los términos naturalismo y tremendismo:

Las armas esgrimidas por los naturalistas radicales no eran las buenas; a lo mejor contribuyeron a banalizar el sexo, espantando mucho, pero hoy su tremendismo nos aparece como una gesticulación, como un grito sin eco. El tremendismo naturalista, por ser ante todo un reto a lo más contingente, a lo más superficial, no pasa el terreno de la contingencia y de la superficialidad ${ }^{70}$.

\section{VIII}

No parece necesario insistir en que el debate sobre el naturalismo dependió en todo momento de la ideología de los litigantes ${ }^{71}$. A esta, además, corresponde una práctica narrativa distinta en cada caso: la novela tradicional del conservador y antinaturalista Alarcón es a todas luces distinta

${ }^{68}$ Diferente de la mía es la opinión de Nil SANTIÁÑEZ TIó, que identifica este naturalismo erótico con una propuesta abiertamente reformista: «El discurso erótico del naturalismo va más allá, por lo demás, de la simple transcripción de pulsiones libidinosas. En su interés por una literatura crítica y comprometida, los naturalistas enmarcan siempre las tendencias eróticas de sus personajes en un contexto social. El erotismo del naturalismo pretende cuestionar, en último término, la política sexual de su sociedad» [«En el umbral de las vanguardias: deseo y subversión en la novela naturalista española», Bulletin Hispanique, 97 (1995), p. 595].

${ }_{69}$ Eduardo López Bago (cit.), p. 133. En p. 6: «Nos encontramos ante una literatura conformada a las necesidades del mercado [...]. En definitiva, un arte de consumo enraizado en la tradición de la literatura popular».

70 «La expresión del erotismo en la novela naturalista española del siglo XIX: eufemismo y tremendismo», Revista Hispánica Moderna, 50 (jun. 1997), p. 45.

${ }^{71}$ Como escribe Eamonn Rodgers, «the reaction to naturalism in Spain tells us less about literature than it does the deep ideological divisions within Spanish society» [«The Reception of Naturalism in Spain», en Brian NELSON (ed.), Naturalism in the European Novel. New Critical Perspectives (Nueva York-Oxford, Berg, 1992), p. 134]. 
de la narrativa renovada que representan los escritores más o menos simpatizantes de la nueva tendencia.

Sabido es, por otra parte, que antes de la polémica naturalista había tenido lugar otro enfrentamiento a propósito del krausismo, cuyos defensores habían sido separados de sus cátedras en 1867. La influencia del positivismo (debatido en el Ateneo madrileño en el curso 1875-76) llegó a ser tal en los ambientes culturales que hubo quien identificó el naturalismo con la vertiente artística de aquel. Como era de esperar, la equiparación no abrió un nuevo frente, pero sí profundizó la brecha que ya existía entre el sector tradicional y su opuesto: el antipositivismo era también antinaturalismo, y viceversa. Un novelista y poeta como José Selgas, más próximo a Fernán Caballero que a la novela sesentayochista, resumía esa postura en 1881: «Al positivismo brutal de la ciencia ha sucedido el realismo grosero del arte, porque a la anarquía de las ideas sucede siempre la corrupción de los sentimientos» ${ }^{72}$.

Ahora bien: ¿ha de deducirse de la presencia del krausismo en los ámbitos culturales más especializados una influencia decisiva en el devenir del naturalismo? Oleza defiende que sí, y que la búsqueda de la síntesis ideal es relacionable con la propuesta filosófica del krausismo. Pero esa síntesis ¿no debe más a una postura conservadora que a otra liberal, como lo era la krausista? Recuérdese la siguiente cita de Pardo Bazán en La cuestión palpitante: «Para mí, no hay más moral que la moral católica, y solo sus preceptos me parecen puros, íntegros, sanos e inmejorables; dicho se está que si un autor bebe sus moralejas en Hegel, Krause o Spencer, las tendré por perniciosas» ${ }^{73}$.

Aludir a la reconocida profesión de fe católica de Pardo Bazán permite hacer referencia a uno de los aspectos más interesantes en el examen de la cuestión naturalista: los intentos que la Iglesia hizo de asimilar la literatura inicialmente considerada vitanda para limar sus asperezas y utilizarla sensu contrario. Algunas notas han sido apuntadas ya por Solange HibbsLissorgues ${ }^{74}$, aunque quepa profundizar en el análisis recurriendo a textos habitualmente olvidados y, sin embargo, sumamente ilustrativos. Por ejemplo, La vizcondesa de Armas (1887), de Juan Armada Losada, Marqués de Figueroa, uno de esos libros (que, por otra parte, tampoco son demasiados) que formarían el corpus de la llamada novela aristocrática, para unos parte del bloque naturalista y para otros integrante del grupo psicológico que lo sustituyó en las preferencias del público y de la crítica.

\footnotetext{
72 «Realismo», Revista Hispano-Americana, 2 (16 oct. 1881), p. 600.

${ }^{73}$ La cuestión palpitante. Ed. de Rosa de Diego. Madrid, Biblioteca Nueva, 1998, p. 265.

${ }^{74}$ Cf. «La Iglesia Católica y el naturalismo», en Y. Lissóngues (ed.), Realismo y naturalismo (cit.), pp. 198-207.
} 
La adscripción de este relato (moderadamente estimable, por otro lado) al naturalismo dice mucho sobre la difuminación de los límites de la corriente. Pero sus evidentes semejanzas con una novela mucho mejor conocida y tradicionalmente vinculada con un hipotético naturalismo católico, Pequeñeces (1890-91), del Padre Coloma, permiten que nos preguntemos por esa desviación ideológica (otra más, aceptada la existencia del decadentismo filomodernista y del espiritualismo individualista) que estrecha lazos entre ideas tan inconciliables (o que parecían tales entonces) como lo eran las de Zola y la religión católica.

Pequeñeces y La vizcondesa de Armas coinciden en más de un aspecto. Por ejemplo, en la inquietud por la educación recibida por los hijos de las familias que se suponía habían de desempeñar el papel rector de la sociedad. O la crítica, implacable, de una nobleza que había perdido el norte y que parecía incapacitada para (e incapaz de) dirigir el rumbo de España. La crítica llega en la primera de ellas a la más acre de las censuras: la culpabilidad salpica tanto a quienes obran inmoralmente como a quienes se muestran pasivos ante la degradación social. Puesto que las implicaciones ideológicas han sido estudiadas por Rubén Benítez en su edición ${ }^{75}$, las obviaré para interesarme por otros aspectos. Por ejemplo, la actitud del $\mathrm{Pa}$ dre Coloma ante Zola (que es tanto como decir ante el naturalismo). Critica un tanto subrepticiamente al escritor francés, pero no por ello se cierra a la evidencia de que existe ese mal que, lógicamente, la religión está obligada a combatir. Pero a la actitud habitual de los escritores entonces llamados idealistas (una Fernán Caballero o un Selgas) Coloma opone su postura: el mal ha de retratarse, aunque sea para ejemplificar aquello que no debe ser aceptado. Es, en el fondo, el mismo planteamiento del naturalismo de Zola, que aspiraba a sacar a la luz las lacras sociales con objeto de sentar las bases precisas para su corrección.

No ha de extrañar, por tanto, que ciertos sectores religiosos y conservadores intentaran hacer suyo el naturalismo para atenuar sus efectos iniciales. Tras las reticencias históricas que habían distanciado la religión del género narrativo parecía llegado el momento de la aproximación, y Peque$\tilde{n}$ eces era un buen pretexto. A este propósito no es ajeno un dato puramente comercial: en 1891 se habían vendido ya nada menos que 30.000 ejemplares de Pequeñeces, según su propio autor. Alguien se percata, por entonces, de que el pernicioso éxito comercial de novelas naturalistas como las de López Bago es posible contrarrestarlo con un triunfo de público similar, pero orientado en un sentido ideológico distinto. Así, en una publicación católica, La Hormiga de Oro, podrá leerse en ese ya tardío 1891 (número del 22 de abril examinado por Hibbs-Lissorgues) que «el natura-

${ }^{75}$ Madrid, Cátedra, ${ }^{5} 1987$. 
lismo al uso puede ser instrumento de bienes prácticos cuando es utilizado por un Coloma o un Pereda».

Con respecto a este último, bastaría quizá recordar que La Montálvez tiene mucho en común con ese naturalismo moralista representado por Figueroa y, sobre todo, Coloma ${ }^{76}$. En su prólogo a la edición de $L a$ Montálvez, L. Bonet recoge una cita procedente de una carta de Pereda a Oller, fechada el 11 de junio de 1885 , en la que el novelista dice sobre Zola: «Si no leo con gran atención a este famoso novelista no es por escrúpulos de conciencia católica ni política, sino porque no puedo digerir su naturalismo desconsolador y antipático» ${ }^{77}$. Y es que en la relación de Pereda con Zola no podemos llegar más lejos que al punto al que alcanza la afirmación del propio Bonet en relación con la obra comentada: «En nuestra novela asistiríamos, en suma, a una cierta vampirización del zolaísmo para, con ello, afianzar una propuesta didáctica abiertamente católica» ${ }^{78}$.

La publicación de Pequeñeces ejemplifica de nuevo la dependencia del enjuiciamiento del fenómeno literario naturalista con respecto a la ideología del intérprete. Nótese, por ejemplo, cómo cada lector vio en la obra

${ }^{76}$ En las páginas 310-22 del libro de Benito MAdARIAGA DE LA CAMPA José María de Pereda. Biografía de un novelista (Santander, Librería Estvdio, 1991) puede seguirse el debate suscitado por La Montálvez. En su tiempo se discutió la proximidad de Pereda al naturalismo, tema que hoy parece superado. No habla de él, por ejemplo, Magdalena AGUINAGA en sus libros El discurso narrativo de Pereda (Santander, Tantín, 1994) y El costumbrismo de Pereda: innovaciones y técnicas narrativas (La Coruña, autora, 1994). El resumen de las ideas actuales sobre el particular podría ser este de Laureano BONET: «Con la perspectiva que nos ofrece el tiempo transcurrido, es evidente que nuestro autor no pretendió conscientemente atravesar la frontera cualitativa, en un sentido ideológico, que separaba el realismo clásico del realismo científico o positivista» [«Pereda y el naturalismo: rastreo de una polémica con Felipe Benicio Navarro», en VV. AA., Nueve lecciones sobre Pereda (Santander, Institución Cultural de Cantabria-Diputación Regional de Cantabria, 1985), p. 164]. Del supuesto naturalismo de Pereda deja de hablarse desde 1889 (La puchera), muy poco antes de que lleguen esos años noventa en que el tema ya no parece interesar. Es una prueba de que se trató de una polémica coyuntural. El propio escritor había sido contundente en su prólogo a De tal palo, tal astilla (1880), si bien obviando las consideraciones de carácter técnico, para resaltar los aspectos temáticos: «Si con tal calificativo se me quiere filiar, como ya se ha hecho, y hasta en son de alabanza, bajo las banderas, triunfantes hoy ultramontes, de un naturalismo hediondo que pinta al desnudo los estragos del alcohol, la inmundicia de los lavaderos y las obscenidades de las mancebías, protesto contra la injuria que de tal modo se me infiere».

77 «Introducción» a J. M. ${ }^{\mathrm{a}}$ DE PEREDA, La Montálvez, en Obras Completas (Santander, Tantín, 1996), VI, p. 420.

${ }^{78}$ Ibíd., p. 450. El alejamiento de Pereda con respecto a la fórmula naturalista se traduce, según María Asunción BLANCO DE LA LAMA, incluso en las características del personaje femenino: «La poca afinidad ideológica que sentía Pereda por el Romanticismo y Naturalismo le lleva a la creación de un personaje femenino que se sustrae a la influencia determinante de estos movimientos» (Novela e idilio en el personaje femenino de José María de Pereda, Santander, Ayuntamiento-Librería Estvdio, 1995, p. 45). 
del Padre Coloma aquello que le interesaba ver. Menéndez y Pelayo alaba su belleza; Valera discrepa de su fondo ideológico; Pardo Bazán niega el naturalismo de Pequeñeces para defender su realismo; Clarín, que en 1881, al reseñar Un viaje de novios, se autotitulaba naturalista empedernido, pero que ahora comenzaba a evolucionar hacia el espiritualismo culminado en Su único hijo y una parte de sus últimos cuentos, critica la escritura en sí, como abstrayéndose de una polémica que ya ha dejado de interesarle.

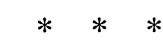

Este conjunto de observaciones en torno al naturalismo puede todavía hoy desarrollarse como tema de carácter monográfico $\mathrm{y}$, por consiguiente, caracterizado por unas notas peculiares que lo distinguen de otros. Pero no debe excluirse la posibilidad de que, si en el futuro los estudiosos optan por relegar los aspectos ideológicos en beneficio de los estilísticos y formales, algún día dejemos de hablar de naturalismo español para concluir que el realismo lo engloba como manifestación natural. En esa fase del análisis podría tener su importancia el desarrollo del concepto de hipotexto romántico, que articularía en una gran unidad de conjunto toda la escritura decimonónica. Cuando M. Sotelo Vázquez escribe el siguiente párrafo está, sin duda, pensando en él:

Si bien es cierto [...] que en Un viaje de novios está el germen del naturalismo pardobazaniano, también lo es que está igualmente presente el del premodernismo de la última etapa, precisamente a través de la pervivencia de la vena romántica. Porque indudablemente el romanticismo se integra como intertextualidad en la estética realista-naturalista ${ }^{79}$.

Aplicar a casos concretos las discutidas divergencias entre el discurso y la práctica naturalistas de Zola quizá resultaría tan rentable como incidir (y ha empezado a hacerse) en los aspectos formales y estilísticos (en el lenguaje, en definitiva) del naturalismo español ${ }^{80}$. Era esta la petición que reiteraba G. Sobejano al comentar que en el congreso celebrado en 1996 sobre el naturalismo «son pocos los trabajos que abordan, en estas Actas, asuntos intrínsecamente literarios o poéticos (invención, estructura, lenguaje: arte)» y plantear la siguiente sugerencia:

79 «Emilia Pardo Bazán: entre el Romanticismo y el Realismo», en L. F. DíAz LARIos y E. Miralles (eds.), Actas del I Coloquio de la Sociedad de Literatura Española del Siglo XIX (cit.), p. 440.

${ }^{80}$ En la divergencia de discursos algo ha empezado a profundizarse. Cf., por ejemplo, el artículo de A. SOTELo VÁzQuEZ, «Los discursos del Naturalismo en España (18811889)», en ibíd., pp. 453-64. 
Reclamaría nueva atención, sin embargo, lo que se pudiera anunciar como una «poética del naturalismo español en su hacerse». Es decir: cómo fue realizándose -en novelas de algunos de esos novelistas, contempladas en simultaneidad y no bajo la separación de cada autor - un cambio de significado y de técnica (de arte) ${ }^{81}$.

He ahí, quizá, el reto de las próximas investigaciones sobre el naturalismo español: ahondar en los elementos estilísticos, estéticos, lingüísticos, formales del naturalismo. En suma, en lo que este tuvo de manifestación artística más que ideológica.

${ }^{81}$ «Epílogo en ausencia», en S. SAILlard y A. Sotelo VÁZquEZ (eds.), Zola y España (cit.), p. 235. 
ÓSCAR BARRERO PÉREZ

\section{RESUMEN}

El desengaño del naturalismo: análisis de la evolución de algunos novelistas españoles del siglo XIX, por Óscar Barrero Pérez.

La evolución de los escritores españoles de la Restauración ejemplifica el constante esfuerzo por asimilar la técnica del naturalismo, sin que esta absorción implicara conformidad con sus presupuestos ideológicos. Entre otros aspectos, se analizan en este artículo las posibilidades de hacer del hipotexto romántico un concepto productivo en la historia de la literatura decimonónica, hasta el punto tal vez de abrir la puerta a la superación de la dialéctica entre realismo y naturalismo, y se apuesta por la atención a los aspectos formales, estilísticos y lingüísticos hasta hoy soterrados por un criterio que prima el contenido del texto.

\section{SUMMARY}

The evolution of the Spanish writers' production during the Restoration exemplifies the constant attempt to assimilate the techniques of Naturalism, without necessarily conforming to its ideological premises. Among other aspects, this essay investigates the possibility of exploiting the idea of «Romantic hypotext» as a productive concept in the history of XIX ${ }^{\text {th }}$ century literature - so as to open the way to the overcoming of the traditional dualism between Realism and Naturalism-, and draws the attention to the formal, stylistic and linguistic aspects of the text so far subordinated to the concern for content. 